\title{
Media Pembelajaran ECO GREEN TERARIUM KHAS SIDOARJO (Miniature Green Art Environment ) Sebagai Media Belajar Green Education Pada Tingkat Sekolah Dasar
}

\author{
Fidaus Su'udiyah ${ }^{1}$, Feri Tirtoni ${ }^{2}$ \\ fidaussuudiyah@umsida.ac.id ${ }^{1}$, feri.tirtoni@umsida.ac.id² \\ Fakultas Keguruan dan Ilmu Pendidikan - Prodi S1-PGSD \\ Universitas Muhammadiyah Sidoarjo
}

\begin{abstract}
Abstrak: Pelaksanaan kegiatan pengabdian masyarakat ibM yang berjudul "IBM Souvenir Eco Green Terrarium mini garden Khas Sidoarjo" tujuan yang ditetapkan adalah melalui kegiatan ini akan tercipta kontribusi yang diberikan kepada mitra 1 dan mitra 2 adalah membentuk KKG (kelompok kerja guru) "SOEGARIUM HARJO" Souvenir Eco Green Terrarium mini garden Khas Sidoarjo yang kemudian diharapkan melalui metode yang telah disusun dapat memberikan kemampuan berupa peningkatan kemampuan dan keterampilan para guru SD setempat untuk bisa mengembangkan SDM mereka menjadi guru yang inovatif dalam mengembangkan media Green Education berbasis Eco Green Terrarium mini garden serta dapat menjadikan produk media yang diciptakan ini nantinya menjadi sebuah media atau sarana dalam mengajarkan Pendidikan Lingkungan Hidup pada level SD serta sebagai media untuk mengaktifkan civitas akademik sekolah dalam melakukan upaya "kampanye hijau" serta kampanye "Sidoarjo Zero Waste" serta nanti nya sebagai produk unggulan lokal sidoarjo , dimana media ini nantinya juga turut menjadi sebuah sarana promosi kota sidoarjo melalui ciri khas icon kota sidoarjo yang melekat pada media Eco Green Terrarium Khas Sidoarjo.Diharapkan melalui adanya pelatihan ketrampilan pembuatan Souvenir terrarium mini garden khas sidoarjo ini meningkatan kemampuan KKG (kelompok kerja guru) dalam menciptakan media pembelajaran inovatif dan kreatif untuk menjawab isu global warming melalui visi green education
\end{abstract}

Kata kunci : Media Pembelajaran, Sekolah Dasar, Green Education, Pendidikan Lingkungan Hidup, Terrarium

\section{ANALISIS SITUASI}

Maraknya pergaulan siswa SD yang kurang peka terhadap isu-isu lingkungan hidup adalah salah satu alasan mengapa diadakannya pelatihan keterampilan pembuatan souvenir Eco Green Terarium Khas Sidoarjo ini, menurut hasil observasi yang dilakukan pada tanggal 20 September 2017 pada mitra 1 dan mitra 2 ditemukan data awal bahwa hampir 90\% guru di masing masing sekolah mitra tidak memahami mengenai konsep media Green Education berbasis Eco Green Terrarium mini garden. Sebab Kondisi sarana dan prasarana sekolah yang ada saat ini tidak memungkinkan adanya suatu aktifitas yang berkaitan dengan pengembangan keterampilan guru dalam mengembangkan media inovatif Green Education 
Fidaus Su'udiyah ${ }^{1}$, Feri Tirtoni ${ }^{2}$

berbasis Eco Green Terrarium mini garden, hal ini dikarenakan minimnya fasilitas pendukung di sana, misalnya tidak adanya sebuah laboratorium sekolah yang bisa digunakan untuk melakukan kegiatan tersebut.

Melihat keadaan lingkungannya yang bersuhu udara ekstrim (panas) seharusnya para guru di kec.Gedangan Sidoarjo mampu menjadi pelopor kampanye hijau salah satunya dimulai dari pengenalan media terrarium sebagai sarana dalam mengajarkan Pendidikan Lingkungan Hidup pada level SD serta sebagai media untuk mengaktifkan civitas akademik sekolah dalam melakukan upaya "kampanye hijau" serta kampanye "Sidoarjo Zero Waste" serta nanti nya sebagai produk unggulan lokal sidoarjo, dimana media ini nantinya juga turut menjadi sebuah sarana promosi kota sidoarjo melalui ciri khas icon kota sidoarjo yang melekat pada media Eco Green Terrarium Khas Sidoarjo. Dalam pembuatan nya nantinya media tanam yang digunakan adalah media yang banyak dijumpai di sekitar kita, seperti kerikil dan pasir halus kita dapat memanfatkan salah satu material dari lingkungan lumpur yang sudah kering selain itu media yang lain yaitu arang, spaghnum moss, zeolit dan kompos. Bahan-bahan media tersebut dapat kita temui di toko-toko pertanian yang ada di sekitar kita. Untuk daerah Sidoarjo, banyak kios pertanian di pinggir-pinggir jalan yang menyediakan bahan-bahan tersebut. Untuk kompos, kita dapat memanfaatkan kompos yang berasal dari pengolahan sampah organik secara mandiri.

Kita dapat menciptakan barang-barang yang mempunyai nilai estetika atau seni unik yang sangat tinggi dan ketersediaan bahan baku yang mudah didapat, murah akan tetapi hasilnya menjadi sangat mahal karena biasanya Terarium ini hanya dinikmati dan dikenal pada kalangan ekonomi menengah ke atas saja karena kebutuhan akan nilai keindahan yang tidak menyita tempat dan tenaga yang banyak karena perawatan Terarium ini sangat mudah pemeliharaannya tidak terlalu intensif (Nurhayati, Susiloarifin. $2004: 54$ )

Profil Mitra 1 (Kelompok Kerja Guru / KKG SDN Wonocolo II), kegiatanya mitra 1 dari segi pelaksanaan pendidikan dan pengajaran pada saat dilakukannya pengamatan dan observasi pada tanggal 20 September 2017 adalah masih kurangnya SDM para guru setempat dalam pembuatan media edukasi serta media inovatif Green Education berbasis Eco Green Terrarium mini garden, hal ini dikarenakan minimnya fasilitas pendukung di sana, misalnya tidak adanya sebuah laboratorium sekolah yang bisa digunakan untuk melakukan kegiatan tersebut. Guru terlambat dalam melakukan pengenalan tentang media terrarium kepada siswa sejak dini kepada siswa, khusunya tidak memahamkan zero waste sebagai sebuah capaian 
Fidaus Su'udiyah ${ }^{1}$, Feri Tirtoni ${ }^{2}$

visi dan misi dari kota Sidoarjo. Disamping itu sekolah ini belum memiliki sebuah program rencana jangka pendek untuk menjadi sekolah adiwiyata.

Sedangkan Profil Mitra 2 (Kelompok Kerja Guru / KKG SDN Kalijaten I). pada umumnya hampir 90\% guru di masing masing sekolah mitra tidak memahami mengenai konsep media Green Education berbasis Eco Green Terrarium mini garden mitra 1 dari segi pelaksanaan pendidikan dan pengajaran, tidak memiliki pengetahuan tentang terrarium, tidak memiliki sekolah contoh model megenai bagaimana cara dan strategi para guru SD dalam merancang sebuah media Green Education berbasis Eco Green Terrarium mini garden secara kreatif melalui pemanfaatan terhadap barang bekas sebagai media nantinya, guna menjawab isu-isu global warming sehingga memberikan pengalaman belajar kepada siswa mengenai proses pembelajaran berbasis lingkungan melalui media Eco Green Terrarium mini garden Dan salah satunya Sebab lainnya mengapa tidak adanya gerakan pengenalan kampanye hijau adalah dikarenakan Kondisi sarana dan prasarana sekolah yang ada saat ini tidak memungkinkan adanya suatu aktifitas yang berkaitan dengan pengembangan keterampilan guru dalam mengembangkan media inovatif Green Education berbasis Eco Green Terrarium mini garden, hal ini dikarenakan minimnya fasilitas pendukung di sana, misalnya tidak adanya sebuah laboratorium sekolah yang bisa digunakan untuk melakukan kegiatan tersebut.

Diharapkan melalui adanya pelatihan ketrampilan pembuatan Souvenir terrarium mini garden khas sidoarjo ini meningkatan kemampuan KKG (kelompok kerja guru) dalam menciptakan media pembelajaran inovatif dan kreatif untuk menjawab isu global warming melalui visi green education

\section{METODE PELAKSANAAN}

\subsection{Metode Pelaksanaan Kegiatan}

Kerangka konseptual prosedur kerja atau alur pelaksanaan program sebagai berikut :

a. Metode sosialisasi "pendekatan dan pemberian pengetahuan mengenai teknis pembuatan produk Souvenir Eco Green Terrarium mini garden Khas Sidoarjo .

Solusi yang ditawarkan pada hari pertama bagi yang paling utama adalah mulai mengenalkan produk media Eco Green Terrarium Khas Sidoarjo kepada mitra 1 dan 2 melalui sebuah Kegiatan Pertama adalah Sosialisasi dimana nantinya ini adalah sebuah starting awal untuk mereka mendapatkan pengetahuan awal mengenai banyak informasi mengenai konsep produk media Eco Green Terrarium Khas Sidoarjo, serta pengenalan media terrarium sebagai sarana dalam mengajarkan 
Fidaus Su'udiyah ${ }^{1}$, Feri Tirtoni ${ }^{2}$

Pendidikan Lingkungan Hidup pada level SD serta sebagai media untuk mengaktifkan civitas akademik sekolah dalam melakukan upaya "kampanye hijau" serta kampanye "Sidoarjo Zero Waste" serta nanti nya sebagai produk unggulan lokal sidoarjo , dimana media ini nantinya juga turut menjadi sebuah sarana promosi kota sidoarjo melalui ciri khas icon kota sidoarjo yang melekat pada media Eco Green Terrarium Khas Sidoarjo . (kegiatan 1 hari full dari pukul $08.00 \mathrm{~s} / \mathrm{d} 12.00$ )

b. Metode Workshop Peningkatan Mutu dan Kualitas pembuatan produk Souvenir Eco Green Terrarium mini garden Khas Sidoarjo.

Setelah kegiatan pertama berlangsung maka pada hari ke dua akan dilaksanakan sebuah Workshop dan pelatihan pembuatan produk cinderamata Terrarium bagi mitra 1 dan 2 dimana nantinya akan diajarkan dan berikan sebuah keterampilan dasar mengenai apa saja yang perlu kita siapkan dalam membuat produk cinderamata Terrarium ini, dan bahan apa saja yang bisa kita manfaatkan dari sekitar lingkungan kita (pemanfaatan bahan dari tanah kompos yang telah di treatment) dalam pelatihan workshop ini nantinya akan dilatih oleh para pakar terrarium dari perkumpulan florish tanaman hias Surabaya yang telah lama berkecimpung dan eksis dalam dunia terrarium dan diasisteni oleh para tenaga sukarelawan dari para mahasiswa teknik pertanian UMSIDA (kegiatan 1 hari full dari pukul $08.00 \mathrm{~s} / \mathrm{d}$ 14.00)

c. Metode Pelatihan dengan tema "Strategi pembelajaran Pendidikan Lingkungan Hidup berbasis media Eco Green Terrarium mini garden Khas Sidoarjo"

Setelah kegiatan kedua berlangsung maka pada hari ke Tiga akan dilaksanakan sebuah Workshop dan pelatihan strategi pembelajaran Pendidikan Lingkungan Hidup berbasis media Eco Green Terrarium mini garden Khas Sidoarjo, hal ini akan dilakukan oleh para tenaga pengajar ahli dari pihak guru "dari sekolah adiwiyata" dalam hal ini akan diwakili oleh 1 orang guru dan 1 orang dosen dari PGSD FKIP Umsida, agar melalui kegiatan terakhir ini mitra 1 dan 2 mendapatkan sebuah role models mengenai bagaimana strategi yang sesuai dalam mengenalkan media Eco Green Terrarium mini garden Khas Sidoarjo pada aktifitas pembelajaran di level Sekolah Dasar sebagai media untuk mengaktifkan civitas akademik sekolah dalam melakukan upaya "kampanye hijau" serta kampanye "Sidoarjo Zero Waste". (kegiatan 1 hari full dari pukul $08.00 \mathrm{~s} / \mathrm{d} 14.00$ ) 
Fidaus Su'udiyah ${ }^{1}$, Feri Tirtoni ${ }^{2}$

d. Metode kontrolling dan pemberian solusi terhadap permasalahan teknis saat pelaksanaan di lapangan

Hal ini dilakukan dengan tujuan agar jika terjadi sebuah permasalan teknis dilapangan yang memerlukan sebuah pemecahan masalah secara cepat maka, melalui metode inilah nantiya akan dihasilkan solusi-solusi dalam setiap teknis dan hambatan yang muncul saat pelakasanaan.

e. Metode Evaluasi dan program pendampingan dalam pembelajaran Pendidikan Lingkungan Hidup berbasis media Eco Green Terrarium mini garden di sekolah mitra 1 dan sekolah mitra 2.

Fungsi dari adanya metode ini adalah agar kita dapat mengetahui indicator pencapaian hasil yang telah dilakukan melalui serangkaian metode dan kegiatan dari awal hingga akhir, dimana nantinya akan muncul sebuah permasalaha yang kemudian melalui metode ini di rumuskan suatu cara untuk menanggulangi nya melalui solusisolusi alternative yang coba akan diberikan oleh team melalui tindakan nyata yaitupada program pendampingan dalam pembelajaran Pendidikan Lingkungan Hidup berbasis media Eco Green Terrarium mini garden di sekolah mitra 1 dan sekolah mitra 2

\section{HASIL DAN PEMBAHASAN}

1. Observasi

Langkah pertama yang harus dilakukan sebelum melakukan tahapan yang lebih khusus ke depan ialah dengan terlebih dahulu melakukan observasi sebelum turun kelapangan, tujuan nya adalah mendapatkan informasi dan gambaran yang jelas mengenai mitra yang akan kita berikan treatment agar diperoleh sebuah hasil yang maksimal dalam pelaksanaan nya nanti. Hasil observasi pertama pada tanggal 4 Desember 2017 ditemukan sebuah gambaran bahwa guru di SD Wonocolo 2 sepanjang belum pernah melakukan praktek pembuatan media pembelajaran berbasis lingkungan dengan menggunakan media terarium. Hal ini cukup menarik sebab kami para tim Pengabdian bisa lebih lanjut untuk berkomunikasi guna mensosialisasikan pentingnya siswa SD dikenalkan sebuah pembelajaran berbasis lingkungan melalui sebuah pelatihan yang akan dilakukan secara bertahap dan secara terprogram pada kegiatan pengabdian kepada masyarakat sekolah Mitra.

Pihak kepala sekolah Yang menaungi ke-2 Mitra tersebut telah bersepakat untuk mengikuti pelatihan pembuatan media pembelajaran untuk pendidikan lingkungan hidup 
Fidaus Su'udiyah ${ }^{1}$, Feri Tirtoni ${ }^{2}$

dengan menggunakan media terrarium. para kepala sekolah memiliki keminatan terhadap pelatihan ini dengan tujuan diharapkan dengan adanya penelitian ini maka akan menjadi sebuah silaturahmi antara sekolah Mitra dan Universitas Muhammadiyah Sidoarjo kedepannya. Selain itu diharapkan juga nantinya melalui pelatihan pembuatan media Green art environment berbasis media terarium yang akan dilakukan oleh tim pengabdian masyarakat umsida akan mampu memberikan sebuah keterampilan skill baru kepada para guru di kedua Mitra agar dapat menambah Khazanah ilmu pengetahuan guru, yang nantinya akan dapat diterapkan pada para siswa dasar pembelajaran mengenal lingkungan hidup di sekolahnya masing-masing.

\section{2. pendekatan dan pemberian pengetahuan mengenai teknis pembuatan produk} Media Eco Green Terrarium mini garden Khas Sidoarjo .

Solusi yang ditawarkan pada hari pertama bagi yang paling utama adalah mulai mengenalkan produk media Eco Green Terrarium Khas Sidoarjo kepada mitra 1 dan 2 melalui sebuah Kegiatan Pertama adalah Sosialisasi dimana nantinya ini adalah sebuah starting awal untuk mereka mendapatkan pengetahuan awal mengenai banyak informasi mengenai konsep produk media Eco Green Terrarium Khas Sidoarjo, serta pengenalan media terrarium sebagai sarana dalam mengajarkan Pendidikan Lingkungan Hidup pada level SD serta sebagai media untuk mengaktifkan civitas akademik sekolah dalam melakukan upaya "kampanye hijau" serta kampanye "Sidoarjo Zero Waste" serta nanti nya sebagai produk unggulan lokal sidoarjo , dimana media ini nantinya juga turut menjadi sebuah sarana promosi kota sidoarjo melalui ciri khas icon kota sidoarjo yang melekat pada media Eco Green Terrarium Khas Sidoarjo. Hal ini disambut baik oleh sekolah mitra 1 dan 2, selain itu diharapkan juga nantinya melalui pelatihan pembuatan media Green art environment berbasis media terarium yang akan dilakukan oleh tim pengabdian masyarakat umsida akan mampu memberikan sebuah keterampilan skill baru kepada para guru di kedua Mitra. (kegiatan 1 hari full dari pukul $08.00 \mathrm{~s} / \mathrm{d} 12.00$, Terlaksana pada Tanggal 6 Januari 2018)

\section{Workshop Peningkatan Mutu dan Kualitas pembuatan produk Media pembelajaran Eco Green Terrarium mini garden Khas Sidoarjo.}

Setelah kegiatan pertama berlangsung maka pada minggu ke dua akan dilaksanakan sebuah Workshop dan pelatihan pembuatan produk cinderamata Terrarium bagi mitra 1 dan 2 dimana nantinya akan diajarkan dan berikan sebuah keterampilan dasar mengenai apa saja yang perlu kita siapkan dalam membuat produk cinderamata Terrarium ini, dan bahan apa saja yang bisa kita manfaatkan dari sekitar lingkungan kita (pemanfaatan bahan dari tanah 
Fidaus Su'udiyah ${ }^{1}$, Feri Tirtoni ${ }^{2}$

kompos yang telah di treatment) dalam pelatihan workshop ini nantinya akan dilatih oleh para pakar terrarium dari perkumpulan florish tanaman hias Surabaya yang telah lama berkecimpung dan eksis dalam dunia terrarium dan diasisteni oleh para tenaga sukarelawan dari para mahasiswa teknik pertanian UMSIDA.

Pada workshop peningkatan mutu dan kualitas produk media pembelajaran berbasis terrarium sudah terlaksana dengan baik, hal ini disambut baik sebab Mitra sekolah merasa bahwa sebuah media yang baik harus didahului dengan sebuah kualitas dan mutu dari media tersebut sehingga layak digunakan dalam sebuah pembelajaran. adapun yang diterangkan dalam kegiatan kedua ini adalah kedua Mitra mulai dikenalkan bahan-bahan yang bisa digunakan dalam proses produksi media pembelajaran lingkungan hidup berbasis terarium melalui benda ramah lingkungan yang ada di sekitar sekolah tempat tinggal siswa. Pelatihan kita awali dengan menggunakan benda-benda yang menjadi bahan dalam pembuatan media pembelajaran pengenalan lingkungan berbasis terarium dimana hal yang dibutuhkan adalah beberapa item yang pertama adalah media tanam disini diajarkan Bagaimana cara memilih media tanam yang baik untuk pembuatan produk media pembelajaran tersebut. media tanam yang dipilih adalah tetap menggunakan bahan dasar tanah sebagai asupan gizi dari tumbuhan Mini yang akan ditanam. namun untuk memaksimalkan dalam hal perawatan maka perlu bisa dilakukan sedimentasi atas media tanam yang dipilih tadi yaitu untuk dasar media tanam dimulai dengan pemberian bahan pecahan atau remahan dari Arang, kemudian sedimen yang kedua adalah tanah bercampur pupuk kompos. Kenapa dipilih pupuk kompos jawabannya adalah agar nantinya media ini tidak memiliki aroma yang menyengat sehingga ramah terhadap Siswa. kemudian setelah itu saya diemin berikutnya adalah tanah berpasir kemudian dilanjutkan dengan lapisan sedimen terakhir yaitu bebatuan kecil yang berfungsi sebagai penahan Agar tanaman Mini tersebut bisa Berdiri berdiri dengan baik pada media tanah. tidak hanya itu sedimen yang terakhir ini juga berfungsi sebagai sebuah aksesoris yang akan menjadikan tampilan media lebih memiliki daya tarik bagi siswa. (kegiatan 1 hari full dari pukul $08.00 \mathrm{~s} / \mathrm{d}$ 14.00, Terlaksana pada Tanggal 13 Januari 2018)

\section{Kegiatan Pelatihan dengan tema "Strategi pembelajaran Pendidikan Lingkungan Hidup berbasis media Eco Green Terrarium mini garden Khas Sidoarjo"}

Setelah kegiatan kedua berlangsung maka pada hari ke Tiga akan dilaksanakan sebuah Workshop dan pelatihan strategi pembelajaran Pendidikan Lingkungan Hidup berbasis media Eco Green Terrarium mini garden Khas Sidoarjo , hal ini akan dilakukan oleh para tenaga pengajar ahli dari pihak guru "dari sekolah adiwiyata" dalam hal ini akan diwakili oleh 1 
Fidaus Su'udiyah ${ }^{1}$, Feri Tirtoni ${ }^{2}$

orang guru dan 1 orang dosen dari PGSD FKIP Umsida, agar melalui kegiatan terakhir ini mitra 1 dan 2 mendapatkan sebuah role models mengenai bagaimana strategi yang sesuai dalam mengenalkan media Eco Green Terrarium mini garden Khas Sidoarjo pada aktifitas pembelajaran di level Sekolah Dasar sebagai media untuk mengaktifkan civitas akademik sekolah dalam melakukan upaya "kampanye hijau" serta kampanye "Sidoarjo Zero Waste".

Maka sampailah kita Pada tahapan ketiga serentetan kegiatan yang telah kita rencanakan sebelumnya. Pada kesempatan kali ini tim pengabdian masyarakat umsida akan melakukan kegiatan pelatihan tentang strategi pembelajaran Pendidikan Lingkungan Hidup berbasis media terrarium pada sekolah Mitra. pada kegiatan kali ini akan dilakukan sebuah penjelasan tentang bagaimana menggunakan media pembelajaran berbasis terrarium ini pada sebuah pembelajaran pengenalan lingkungan hidup bagi siswa SD. yang dimulai dengan memberikan pelatihan mengenai pemetaan kompetensi dasar yang berada pada tiap-tiap level kelas. semisal pada kelas rendah 12 dan 3, maka tentunya hal ini dilakukan dengan cara edukasi kepada siswa tersebut tentang bagaimana media ini nantinya sebagai sebuah fasilitas yang akan mendekatkan siswa untuk lebih merespon tentang keberadaan lingkungan di sekitar mereka dengan cara memiliki dan merawat tanaman Mini yang bisa mereka buat untuk belajar tentang inti dari sikap peduli dan mencintai lingkungan hidup. sedangkan pada kelas atas yaitu 45 dan 6 meja ini berfungsi lebih pada pengenalan terhadap fungsi-fungsi dari bahanbahan yang ada pada media ini, semisal fungsi-fungsi dari media tanam, media sedimen yang digunakan untuk media tanam, serta jenis dari masing-masing tanaman Mini yang digunakan pada media terarium ini. guru diharapkan dapat merancang sebuah pembelajaran yang lebih kreatif dan inovatif melalui adanya media pembelajaran berbasis terarium tersebut. hal itu bisa dilakukan dengan terlebih dahulu menyusun sebuah rancangan pembelajaran yang didalamnya nantinya bisa memaksimalkan keberadaan dari produk media terrarium yang sudah dibuat, sehingga bisa dimaksimalkan dalam pengaplikasiannya melalui strategi pembelajaran pengenalan lingkungan hidup berbasis media terarium. pada pelatihan kali ini semua berjalan dengan baik tanpa menemui hambatan. dan para peserta latihan di sekolah Mitra ini dapat memahami dengan baik penjelasan dari narasumber. (kegiatan 1 hari full dari pukul $08.00 \mathrm{~s} / \mathrm{d}$ 14.00, Terlaksana pada Tanggal 20 Januari 2018).

Setelah terlaksananya kegiatan sosialisasi media terarium dan pelatihan pembuatan produk media tersebut, maka rencana tindak lanjut ke depan adalah melakukan sebuah controlling dan pemberian solusi terhadap permasalahan teknis saat pelaksanaan di lapangan. hal ini akan dilakukan sepekan setelah pembelajaran dilakukan. diharapkan guru pada sekolah 
Fidaus Su'udiyah ${ }^{1}$, Feri Tirtoni ${ }^{2}$

Mitra melakukan sebuah pencatatan dalam bentuk jurnal pada saat selesai melakukan pembelajaran dalam hal ini nanti akan diketahui deskripsi permasalahan yang muncul pada saat pembelajaran berlangsung dengan menggunakan media lingkungan hidup berbasis terarium. dalam kegiatan ini nantinya akan dilakukan sebuah pemberian solusi alternatif agar pembelajaran pengenalan lingkungan hidup berbasis terarium melalui berbasis terarium tersebut bisa berjalan dengan baik Sesuai tujuan pembelajaran yang diharapkan. setelah itu rencana ke depan adalah melakukan sebuah evaluasi terhadap hasil-hasil yang telah dicapai agar kemudian segala permasalahan yang ada pada saat pembelajaran dengan menggunakan teknik pemberian media berbasis terarium diperoleh sebuah gambaran dan deskripsi mengenai keunggulan dan kekurangan yang ada pada sistem pembelajaran berbasis media terarium tersebut. Adapun rencana tahap berikut nya adalah adalah pelaksanaan 2 tahap kegiatan yang menggunakan metode kontroling dan evaluasi guna menyempurnakan kegaiatan yang telah terlaksana sebelumnya.

\section{Kegiatan kontrolling dan pemberian solusi terhadap permasalahan teknis saat pelaksanaan di lapangan}

Hal ini dilakukan dengan tujuan agar jika terjadi sebuah permasalan teknis dilapangan yang memerlukan sebuah pemecahan masalah secara cepat maka, melalui metode inilah nantiya akan dihasilkan solusi-solusi dalam setiap teknis dan hambatan yang muncul saat pelakasanaan. (Kegiatan ini akan direncanakan 1 hari full dari pukul $08.00 \mathrm{~s} / \mathrm{d}$ 14.00, direncanakan pelaksanaanya pada Tanggal 27 Januari 2018).

Menurut hasil dari pertemuan pada mitra 1 maupun mitra 2 pada pada Tanggal 27 Januari 2018, disampaikanlah beberapa permasalahan terkait hambatan pada pelaksanan pembelajaran Pendidikan Lingkungan Hidup berbasis media Eco Green Terrarium mini garden di sekolah mitra 1 dan sekolah mitra 2 adapun beberapa permasalahan berserta solusi yang telah kami himpun melalui kegiatan ini yaitu :

\section{a. Tidak adanya Ketersediaan media tanaman kaktus mini}

Pada pertemuan kali ini Mitra 1 dan 2 menyampaikan bahwa tidak adanya media tanam yaitu tanaman kaktus menjadikan sebuah penghambat tersendiri, sebab terrarium Dianggap tidak lengkap tanpa adanya tanaman Mini kaktus. maka solusi yang kami tawarkan adalah memberikan pengertian bahwa terrarium tidak harus identik dengan tanaman kaktus. sebab pada intinya terrarium adalah sebuah sistem menanam dengan media kecil bisa diaplikasikan pada ruangan indoor maupun outdoor. kita memberikan pemahaman kepada guru Mitra 1 dan 2 bahwa tanaman kaktus bisa diganti dengan 
Fidaus Su'udiyah ${ }^{1}$, Feri Tirtoni ${ }^{2}$

tanaman lain yang juga memiliki ukuran kecil seperti tanaman hydra atau sejenis rerumputan liar yang memiliki bunga serta memanfaatkan lumut hijau sebagai salah satu media aplikasi pada tanaman terarium. intinya adalah kita memberikan pemahaman kepada para guru agar lebih kreatif dalam melakukan desain terhadap model media terrarium melalui pemanfaatan tanaman yang ada di sekitar lingkungan tempat tinggal maupun lingkungan sekolah. agar siswa terbiasa kreatif dalam memanfaatkan benda di sekitar mereka

b. Pola perilaku adaptif siswa dan wali murid yang masih berorientasi bahwa tren menanam dengan media terrarium tidak cocok diterapkan pada siswa SD

Adapun permasalahan yang kami temukan ada saat melakukan diskusi dengan Mitra 1 dan 2 , yaitu adanya sebuah pola pemikiran lama yang masih dimiliki oleh wali murid yang kurang mendukung pelaksanaan kegiatan pembelajar melalui media pembelajaran mini garden terrarium, yang mereka anggap tidak memiliki sebuah manfaat sebab hasil tanam nya nantinya tidak menghasilkan buah ataupun sayuran yang pada saat tanaman tersebut tumbuh dan dipanen. maka dengan kondisi ini kita memberikan sebuah pendekatan kepada wali murid dan siswa melalui guru bahwa budaya menanam ada siswa usia SD lebih baik dimulai dari hal yang sifatnya sederhana, dan tidak memerlukan sebuah perawatan khusus pada tanaman tersebut setiap harinya, Hal ini dilakukan untuk menghindari kejenuhan oleh siswa. sebab dunia siswa pada tahap ini adalah masih bermain sambil belajar. terarium adalah jawaban dari permasalahan ini sebab melalui kegiatan pembuatan media pembelajaran berbasis terrarium tersebut secara langsung memiliki imbas kepada siswa untuk memunculkan sebuah karakter peduli terhadap lingkungan sekitar Melalui aktivitas menanam pada media kecil dan sederhana yang diaplikasikan melalui bentuk media terarium terrarium . hal ini pun sesuai dengan hasil penelitian (Sumitro Husodo 2015) yang mengatakan bahwa siswa membutuhkan sebuah pengalaman belajar yang diperoleh pada saat dan sehari-hari di sekolah, budaya menanam tanaman Mini akan memberikan sebuah pengalaman belajar menyenangkan bagi siswa sehingga memunculkan karakter peduli lingkungan sejak dini.

\section{c. Perlunya guru untuk melakukan integrasi pada RPP mapel yang bisa dintegrasikan PLH}

Hambatan berikutnya adalah masih adanya guru ada Mitra 1 dan Mitra 2 yang nampaknya belum memiliki kesiapan untuk melakukan sebuah perubahan pada perangkat pembelajaran sehingga memungkinkan untuk dilakukannya integrasi muatan pendidikan 
Fidaus Su'udiyah ${ }^{1}$, Feri Tirtoni ${ }^{2}$

lingkungan hidup atau green education . solusi yang kami tawarkan adalah memberikan sebuah pelatihan pada guru dalam pembuatan Silabus dan RPP pada hari itu juga, yang didalamnya terdapat integrasi sejarah monolitik muatan pendidikan lingkungan hidup atau green education. Sehingga nantinya bisa diaplikasikan pada saat pembelajaran , sehingga sekolah ini nantinya memiliki sebuah embrio sebagai persiapan menuju sekolah calon adiwiyata.

d. Adanya sebuah usulan agar dibentuk sebuah program gerakan sekolah hijau untuk mengiatkan kampanye green education atau pendidikan lingkungan hidup di lingkungan sekolah - dana CSR

Adanya sebuah usulan untuk menciptakan sebuah program sekolah yang dapat menunjang pembelajaran lingkungan hidup sekolah Mitra 1 dan 2 melalui sebuah program gerakan sekolah hijau untuk mengiatkan kampanye green education atau pendidikan lingkungan hidup di lingkungan sekolah. hal ini akan kita sambut baik dengan cara memberikan sebuah kisi-kisi kegiatan yang nantinya bisa ditindaklanjuti kedepannya untuk melaksanakan program baru ini. Selain itu kami menyampaikan juga berkaitan dengan hal ini tentunya ke depan pasti memerlukan sebuah dukungan dana untuk melaksanakan program ini, maka program CSR adalah sebuah solusi dalam mencari stakeholder guna mensponsori dan mendanai kegiatan ini di masa mendatang, Oleh sebab itu semua portofolio kegiatan harus disiapkan dari tahun pertama ini.

\subsection{Kegiatan Evaluasi dan program pendampingan dalam pembelajaran Pendidikan} Lingkungan Hidup berbasis media Eco Green Terrarium mini garden di sekolah mitra 1 dan sekolah mitra 2.

Fungsi dari adanya metode ini adalah agar kita dapat mengetahui indicator pencapaian hasil yang telah dilakukan melalui serangkaian metode dan kegiatan dari awal hingga akhir, dimana nantinya akan muncul sebuah permasalaha yang kemudian melalui metode ini di rumuskan suatu cara untuk menanggulangi nya melalui solusi-solusi alternative yang coba akan diberikan oleh team melalui tindakan nyata yaitu pada program pendampingan dalam pembelajaran Pendidikan Lingkungan Hidup berbasis media Eco Green Terrarium mini garden di sekolah mitra 1 dan sekolah mitra 2.(Kegiatan ini akan direncanakan 1 hari full dari pukul $08.00 \mathrm{~s} / \mathrm{d} 14.00$, direncanakan pelaksanaanya pada Tanggal 27 Januari 2018)

Setelah dilaksanakannya Kegiatan Evaluasi dan program pendampingan dalam pembelajaran Pendidikan Lingkungan Hidup berbasis media Eco Green Terrarium mini 
Fidaus Su'udiyah ${ }^{1}$, Feri Tirtoni ${ }^{2}$

garden di sekolah mitra 1 dan sekolah mitra 2 maka kita memperolah data bahwa.Pelaksanaan kegaiatan berjalan $95 \%$ sesuai dengan rencana yang telah ditetapkan

\section{SIMPULAN}

Kegiatan pengabdian terhadap Sekolah Mitra 1 dan 2 telah terlaksana dengan sangat baik hal ini dapat dilihat dari terlaksananya 3 kegiatan besar yang telah berjalan dengan sesuai rencana dan target yang telah direncanakan

Adapun 3 kegiatan yang telah terlaksana adalah :

a. Kegiatan pendekatan dan pemberian pengetahuan mengenai teknis pembuatan produk media pembelajaran Eco Green Terrarium mini garden Khas Sidoarjo . (Kegiatan 1 hari full dari pukul $08.00 \mathrm{~s} / \mathrm{d}$ 12.00, Terlaksana pada Tanggal 6 Januari 2018)

b. Workshop Peningkatan Mutu dan Kualitas pembuatan produk media pembelajaran Eco Green Terrarium mini garden Khas Sidoarjo (kegiatan 1 hari full dari pukul $08.00 \mathrm{~s} / \mathrm{d}$ 14.00, Terlaksana pada Tanggal 13 Januari 2018)

c. Kegiatan Pelatihan dengan tema "Strategi pembelajaran Pendidikan Lingkungan Hidup berbasis media Eco Green Terrarium mini garden Khas Sidoarjo" (kegiatan 1 hari full dari pukul $08.00 \mathrm{~s} / \mathrm{d}$ 14.00, Terlaksana pada Tanggal 20 Januari 2018).

d. Kegiatan kontrolling dan pemberian solusi terhadap permasalahan teknis saat pelaksanaan di lapangan Kegiatan ini terlaksana 1 hari full dari pukul $08.00 \mathrm{~s} / \mathrm{d}$ 14.00, direncanakan pelaksanaanya pada Tanggal 27 Januari 2018

e. Kegiatan Evaluasi dan program pendampingan dalam pembelajaran Pendidikan Lingkungan Hidup berbasis media Eco Green Terrarium mini garden di sekolah mitra 1 dan sekolah mitra 2. Kegiatan ini terlaksana 1 hari full dari pukul $08.00 \mathrm{~s} / \mathrm{d} 14.00$, dan pelaksanaanya pada Tanggal 27 Januari 2018)

Adapun saran yang direkomendasikan kebakaran sekolah Mitra adalah sebaiknya upaya pengenalan terhadap lingkungan hidup dilakukan sedini mungkin sehingga terbiasa dengan habituasi yang ada. sistem pendidikan di sekolah disusun sedemikian rupa sehingga visi misi sekolah memiliki sebuah ruang lingkup yang memungkinkan pembelajaran berbasis lingkungan hidup dengan menggunakan media terrarium ataupun media lainnya dilaksanakan dengan baik pada kelas rendah maupun kelas tinggi. Kedua yaitu perlunya guru untuk mengetahui dan mengakses informasi dari sekolah Mitra lainnya yang telah lebih dulu mengawali pembelajaran pengenalan lingkungan hidup berbasis media terarium, agar 
Fidaus Su'udiyah ${ }^{1}$, Feri Tirtoni ${ }^{2}$

memiliki pengetahuan awal yang cukup mengenai ruang lingkup produk media pembelajaran tersebut

\section{DAFTAR PUSTAKA}

Charina, A., Kusumo, R.A.B., dan Deliana, Y.,' Terrarium Sebagai Solusi Cara Bercocok Tanam Hemat Air, Lahan, Serta Pengurangan Polutan Pabrik Di Desa Nasol Dan Sindangsari Kecamatan Cikoneng Kabupaten Ciamis', jurnal.unpad.ac.id/dharmakarya/article/download/8189/3739 https://www.google.co.id/?gws rd=cr,ssl\&ei=MbpLV6_DLsPzvATQq42wCw\#q=jur nal+terrarium, diakses 18 Mei 2016

Lili Sugiyarto, M.Si,' Struktur dan Fungsi Terarium sebagai Miniatur Ekosistem', http://staff.uny.ac.id/sites/default/files/pengabdian/lili-sugiyarto-ssi-msi/miniaturekosistem.pdf, diakses 21 Mei 2016

Mufliah, Iin Mutia, Tumisem,' Pengembangan Terarium Untuk Meningkatkan Kreativitas Masyarakat Sekolah Dan Masyarakat Desa Kemutug Lor Kecamatan Baturaden', http://prosiding.upgrismg.ac.id/index.php/enter_2/entre_2/paper/viewFile/749/702, diakses 26 Mei 2016.

Nurhayati, Susiloarifin. 2004. Pembuatan Terarium. Jakarta: Gramedia Press

Kristiani, Anie. 2008. Membuat Terarium; Taman Mungil dalam Kaca . Jakarta: Agromedia Pustaka .

Kristiani, Anie. 2008. Membuat Terarium, dari Hobi menjadi Bisnis. Jakarta: PT Agromedia Pustaka.

Budhiprawira, S. dan D. Saraswati. 2006. Anthurium. Jakarta: Penebar Swadaya.

Triharyanto, E. dan J. Sutrisno, 2007. Si Kaya Silangan : Anthurium Hookeri. Jakarta: Pustaka Tanam.

Wijayani, A. 2007. Anthurium Tanaman Daun Eksotik. Yogyakarta: Kanisius.

Yusnita. 2003. Kultur Jaringan Cara Memperbanyak Tanaman secara Efisien. Jakarta: Agromedia Pustaka.

Endah, J. H. dan Tim Lentera. 2002. Mempercantik Kaktus dan Meningkatkan Nilai Jualnya. Jakarta: Agro media Pustaka.

Redaksi Flona. 2007. Daun Bunga Anthurium Mewah dan Fenomenal. Jakarta: Samindra Utama. 